\title{
Mathematical Model to Predict Conductive Properties of Contaminated Riverbed Sand in Ado-Odo Ota Local Government Area of Ogun State, Nigeria
}

\author{
Olukayode D. Akinyemi ${ }^{1}$ Jamiu A. Rabiu ${ }^{1}$, V. C. Ozebo ${ }^{1} \&$ O. A. Idowu ${ }^{2}$ \\ ${ }^{1}$ Department of Physics, University of Agriculture, Abeokuta, Ogun State, Nigeria \\ ${ }^{2}$ Department of Water Resources Management and Agrometeorology, University of Agriculture, Abeokuta, \\ Ogun State, Nigeria \\ Correspondence: Jamiu A. Rabiu, Department of Physics, University of Agriculture, Abeokuta, Ogun State, \\ Nigeria. E-mail: jamoary@yahoo.com
}

\author{
Received: February 1, 2012 Accepted: February 14, 2012 Online Published: June 5, 2012 \\ doi:10.5539/esr.v1n2p43 \\ URL: http://dx.doi.org/10.5539/esr.v1n2p43
}

\begin{abstract}
The possibility of contamination is especially rising due to the increase in the number of industries in the Local Government Area. In this study, riverbed sands were collected from five major rivers in Ado-Odo Ota Local Government Area, and conductivity properties were determined after the samples have been treated with varying concentration of petrol, engine oil, diesel, caustic soda and $\mathrm{H}_{2} \mathrm{SO}_{4}$. HANNAN Electrical Conductivity Meter, KD2 Thermal Conductivity Meter and Constant Head Method were used to determine the electrical, thermal and hydraulic conductivities respectively. A mathematical model was developed that describes the effect of contaminants on the electrical $(\sigma)$, thermal $(\lambda)$ and hydraulic $(\mathrm{k})$ conductivities of riverbed sand from the major rivers in Ado-odo Ota Local Government Area. The model equation incorporates the bulk density of the riverbed sand samples, as well as the concentration and conductivity of the contaminants as follows: $\lambda=0.107 \mathrm{x}_{1}+0.10 \mathrm{x}_{2}$ $-0.017 \mathrm{x}_{3}+1.673, \sigma=1.911 \mathrm{x}_{1}+18.229 \mathrm{x}_{2}-0.015 \mathrm{x}_{3}+47.173$ and $\mathrm{k}=0.056 \mathrm{x}_{1}+0.381 \mathrm{x}_{2}-0.031 \mathrm{x}_{3}+0.162$, where $\mathrm{x}_{1}, \mathrm{x}_{2}$ and $\mathrm{x}_{3}$ are bulk density of samples, conductivity and concentration of contaminants respectively. From interpolation analysis, sample from Ilogbo river contained about $30 \mathrm{ml} / \mathrm{kg}$ of engine oil, Mosafejo river contained about $10 \mathrm{ml} / \mathrm{kg}$ of caustic soda, Ijako river contained about $20 \mathrm{ml} / \mathrm{kg}$ of caustic soda, Iju river contained about $10 \mathrm{ml} / \mathrm{kg}$ of diesel and Igbogbo river contained $10 \mathrm{ml} / \mathrm{kg} \mathrm{of} \mathrm{H}_{2} \mathrm{SO}_{4}$, thus showing clearly how waste products from industries end up as contaminants in nearby rivers.
\end{abstract}

Keywords: mathematical model, riverbed sand, thermal conductivity, electrical conductivity, hydraulic conductivity, contaminants concentration

\section{Introduction}

Pollution of the soil environment with petroleum and refinery products is one of the factors expressing anthropopression. Due to its toxicity, widespread presence and complex nature, this type of pollution is a serious problem, one reason being that as the modern civilisation, urbanisation and mechanisation develop, the use of petroleum and petroleum-based products grows. Contamination of soils with crude oil and refinery products is becoming an ever-increasing problem, especially in the light of several breakdowns of oil pipelines and wells reported recently. Nonetheless, major points of soil pollution with refinery products are petrol stations, garages servicing cars and tractors, seaport areas (Michalcewicz, 1995). Other areas of concern are mining and distribution of petroleum-based products (Song \& Barhta, 1990, Amadi et al., 1996, Jørgensen et al., 2000). Besides, heavy use of machinery in agriculture leads to higher consumption of diesel oil. Certain negligence when transporting, collecting or storing refinery products together with unsatisfactory care while disposing of old or used petroleum products lead to considerable pollution of the natural environment (Leahy \& Colwell, 1990). Petroleum and refinery products penetrating soil cause its degradation (Sztompka, 1999). Once they enter an ecosystem, petroleum-based products initiate a series of processes, affecting both its biotic and abiotic elements (Małachowska-Jutsz et al., 1997). Crude oil and products derived from this raw material are composed of aliphatic, oleic, naphthenic and aromatic hydrocarbons (Chi \& Krishnamurthy, 1995), which modify physical and chemical properties of soil and its structure. These compounds are largely responsible for changed fertility of 
soil (Tyczkowski, 1993, Iwanow et al., 1994). Soil polluted by petroleum-based products loses its biological activity and may not be able to recover it over ten years (Sparrow \& Sparrow, 1988, Racine 1993, Wyszkowska et al., 2001). Moreover, diesel oil has a negative effect on the biochemical and physicochemical characteristics of soils (Tyczkowski, 1993, Kucharski \& Wyszkowska, 2001, Wyszkowska et al., 2002).

Since contamination of soil with refinery products deteriorates its biochemical and physicochemical properties, it also limits the growth and development of plants, whose nutritive and technological value can be low and often questionable. In this connection, the present study has been undertaken to determine the effect of soil contamination with Diesel oil, Engine oil, Petrol, Caustic soda and $\mathrm{H}_{2} \mathrm{SO}_{4}$ on thermal, electrical and hydraulic conductivities, and to determine the predictive mathematical models for the physical properties.

\section{Study Area}

The study was carried out on five major rivers in Ado-Odo/Ota Local Government Area of Ogun State. Ado-odo/Ota Local Government is one of the 20 Local Government areas of Ogun State located in the West Senatorial District. Geographically, it is situated within the tropical zone lying between $60^{\circ}$ and $47^{\circ} \mathrm{N}$ of equator and $20.33^{\circ} \mathrm{E}$ and $30.18^{\circ} \mathrm{E}$ of the Greenwich's Meridian and covers a land area of 1,263 square kilometers with a Terrain of 1,010.4 sq kilometer plain land and about 252.6 square kilometers. Terrain comprises of $16 \%$ riverine and 4\% hilly regions. The Local Government has an estimated population of 527,242 people (Male 262,523 \& Female 265,719) (2006 Census) with about four hundred and fifty (450) towns, villages and settlements. The map shown in Figure 1, illustrate the location of the sampling sites and the potential source of pollutants, which include agricultural wastes, industrial wastes, sewage, animal wastes, market wastes, etc. Three of the rivers (Ilogbo, Mosafejo and Ijako rivers) are located in the southern district of the area. While the remaining two (Igbogbo and Iju rivers) are located in the northern part of area. The Ijako and Ilogbo Rivers are particularly unique for several reasons. The Ijako community has undergone great economic development in recent years and is notably one of the fastest growing economically important communities in Ado-odo/ota L.G.A. which accommodates a considerable number of micro- industries (Coca-Cola Nig. Ltd, Sona Breweries plc, Universal Gas Ltd, Nigeria Foundries Ltd, 3Ace lnd. Ltd and Fine chemicals ltd.).The very popular market (Ilogbo market) and the timber business coupled with agricultural practices have drawn people from several cultural background in the country to make the settlement inter- tribal. This increase in anthropogenic activities surrounding the area has lead to an increase in environmental degradation. These multiple sources make it especially difficult to identify and isolate the risks associated with this contaminated water.

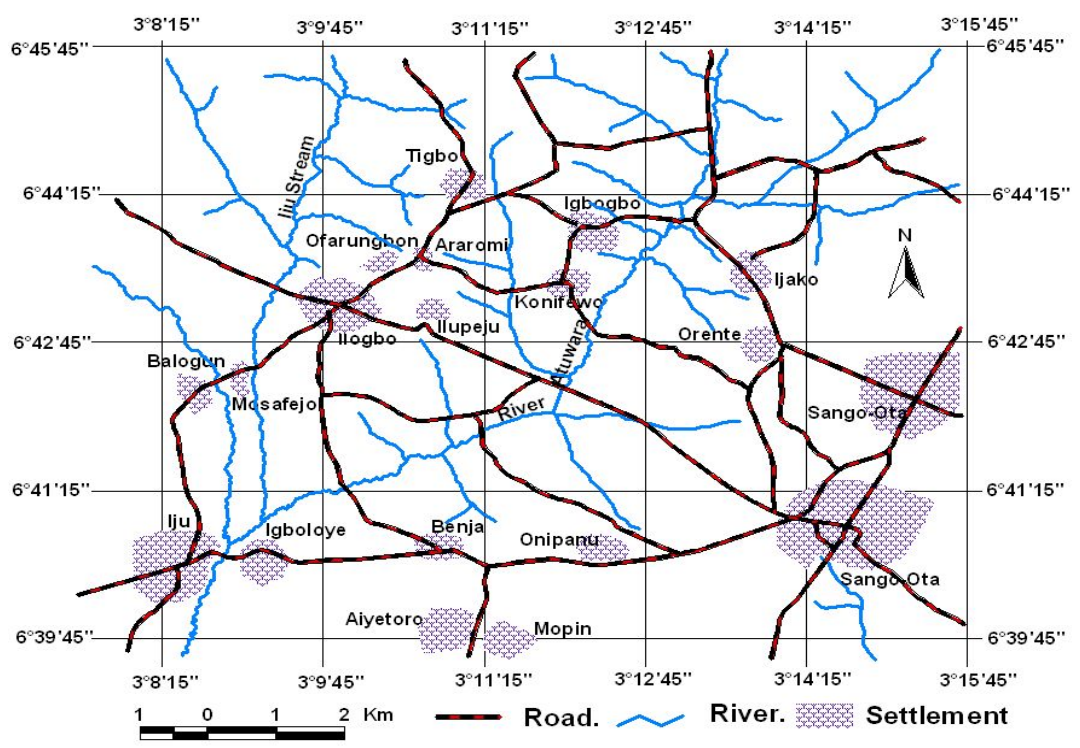

Figure 1. Map of study area

\section{Materials and Methods}

The equipments used in this work included Hannan electrical conductivity meter, KD2 thermal conductivity meter and Digital weight balance. Riverbed sands were collected from the five major rivers present in Ado-Odo 
Ota Local Government Area of Ogun state. Surface sediment sample were collected manually from the rivers' bank, transferred into plastic containers, and transported to the laboratory (UNAAB). Samples collected were thoroughly washed to remove any hidden contaminant, air dried and sieved to ensure uniform grain size. $1.3 \mathrm{~g} / \mathrm{cm}^{3}$ bulk density of each treated sample were moistened with uniform grain size of $0.2 \mathrm{~mm}$. Five readings of thermal conductivity and electrical conductivity were taken at different points in the cylinder in order to obtain the average values, after which the hydraulic conductivity was measured using constant head method. $5 \mathrm{ml}$ of each contaminant was added and mixed thoroughly.

\section{Results and Discussion}

Table 1. ANOVA Table for conductivity properties of Riverbed sands

Tests of Between-Subjects Effects

\begin{tabular}{|c|c|c|c|c|c|c|}
\hline Source & Dependent Variable & $\begin{array}{l}\text { Type III Sum } \\
\text { of Squares }\end{array}$ & df & Mean Square & $\mathrm{F}$ & Sig. \\
\hline \multirow[t]{3}{*}{ Corrected Model } & Thermal Conductivity & $85.302^{\mathrm{a}}$ & 60 & 1.422 & 32.359 & .000 \\
\hline & Electrical Conductivity & $291562.322^{b}$ & 60 & 4859.372 & 230.467 & .000 \\
\hline & Hydraulic Conductivity & $74.213^{c}$ & 60 & 1.237 & 29.020 & .000 \\
\hline \multirow[t]{3}{*}{ Intercept } & Thermal Conductivity & 518.814 & 1 & 518.814 & 11808.518 & .000 \\
\hline & Electrical Conductivity & 1440968.749 & 1 & 1440968.749 & 68341.241 & .000 \\
\hline & Hydraulic Conductivity & 125.521 & 1 & 125.521 & 2944.959 & .000 \\
\hline \multirow[t]{3}{*}{ Sample } & Thermal Conductivity & 7.236 & 4 & 1.809 & 41.175 & .000 \\
\hline & Electrical Conductivity & 1308.401 & 4 & 327.100 & 15.513 & .000 \\
\hline & Hydraulic Conductivity & 3.184 & 4 & .796 & 18.678 & .000 \\
\hline \multirow[t]{3}{*}{ Contaminant } & Thermal Conductivity & 31.157 & 4 & 7.789 & 177.288 & .000 \\
\hline & Electrical Conductivity & 237296.004 & 4 & 59324.001 & 2813.577 & .000 \\
\hline & Hydraulic Conductivity & 55.921 & 4 & 13.980 & 328.004 & .000 \\
\hline \multirow[t]{3}{*}{ Concentration } & Thermal Conductivity & 1.881 & 4 & .470 & 10.704 & .000 \\
\hline & Electrical Conductivity & 57.719 & 4 & 14.430 & .684 & .605 \\
\hline & Hydraulic Conductivity & 6.144 & 4 & 1.536 & 36.039 & .000 \\
\hline \multirow[t]{3}{*}{ Sample * Contaminant } & Thermal Conductivity & 13.759 & 16 & .860 & 19.573 & .000 \\
\hline & Electrical Conductivity & 6563.030 & 16 & 410.189 & 19.454 & .000 \\
\hline & Hydraulic Conductivity & 6.126 & 16 & .383 & 8.982 & .000 \\
\hline \multirow[t]{3}{*}{ Sample * Concentration } & Thermal Conductivity & 1.068 & 16 & .067 & 1.519 & .121 \\
\hline & Electrical Conductivity & 185.115 & 16 & 11.570 & .549 & .909 \\
\hline & Hydraulic Conductivity & 1.320 & 16 & .083 & 1.936 & .033 \\
\hline \multirow{3}{*}{$\begin{array}{l}\text { Contaminant * } \\
\text { Concentration }\end{array}$} & Thermal Conductivity & 30.201 & 16 & 1.888 & 42.962 & .000 \\
\hline & Electrical Conductivity & 46152.053 & 16 & 2884.503 & 136.804 & .000 \\
\hline & Hydraulic Conductivity & 1.518 & 16 & .095 & 2.226 & .013 \\
\hline \multirow[t]{3}{*}{ Error } & Thermal Conductivity & 2.812 & 64 & .044 & & \\
\hline & Electrical Conductivity & 1349.434 & 64 & 21.085 & & \\
\hline & Hydraulic Conductivity & 2.728 & 64 & .043 & & \\
\hline \multirow[t]{3}{*}{ Total } & Thermal Conductivity & 606.927 & 125 & & & \\
\hline & Electrical Conductivity & 1733880.505 & 125 & & & \\
\hline & Hydraulic Conductivity & 202.462 & 125 & & & \\
\hline \multirow[t]{3}{*}{ Corrected Total } & Thermal Conductivity & 88.113 & 124 & & & \\
\hline & Electrical Conductivity & 292911.756 & 124 & & & \\
\hline & Hydraulic Conductivity & 76.941 & 124 & & & \\
\hline
\end{tabular}

a. $\mathrm{R}$ Squared $=.968$ (Adjusted R Squared $=.938$ )

b. $\mathrm{R}$ Squared $=.995$ (Adjusted $\mathrm{R}$ Squared $=.991)$

c. $\mathrm{R}$ Squared $=.965$ (Adjusted R Squared $=.931$ )

From Table 1, thermal conductivity, electrical conductivity and hydraulic conductivity of different sand samples differ significantly at $5 \%(\mathrm{p}<0.05)$ level of significance. It is also observed from the table that these three properties differ significantly for the different contaminants used on the sand samples, but this is not the case for the different concentration of the contaminants. Rather it is seen that while the thermal and hydraulic 
conductivities differ significantly at $5 \%$ level for the different concentration of contaminants used, electrical conductivity is not significantly different at $5 \%$ level.

Table 2. Mean values of the different conductivity properties for the different sand samples

\begin{tabular}{|c|c|c|c|c|c|}
\hline \multicolumn{6}{|c|}{ 2. Sample } \\
\hline \multirow[b]{2}{*}{ Dependent Variable } & \multirow[b]{2}{*}{ Sample } & \multirow[b]{2}{*}{ Mean } & \multirow[b]{2}{*}{ Std. Error } & \multicolumn{2}{|c|}{ 95\% Confidence Interval } \\
\hline & & & & Lower Bound & Upper Bound \\
\hline \multirow[t]{5}{*}{ Thermal Conductivity } & Sample A & 1.923 & .042 & 1.839 & 2.007 \\
\hline & Sample B & 2.024 & .042 & 1.940 & 2.108 \\
\hline & Sample C & 1.665 & .042 & 1.581 & 1.749 \\
\hline & Sample D & 2.207 & .042 & 2.123 & 2.291 \\
\hline & Sample E & 2.367 & .042 & 2.283 & 2.451 \\
\hline \multirow[t]{5}{*}{ Electrical Conductivity } & Sample A & 103.543 & .918 & 101.708 & 105.377 \\
\hline & Sample B & 107.550 & .918 & 105.715 & 109.385 \\
\hline & Sample C & 104.128 & .918 & 102.293 & 105.963 \\
\hline & Sample D & 109.484 & .918 & 107.649 & 111.319 \\
\hline & Sample E & 112.132 & .918 & 110.297 & 113.967 \\
\hline \multirow[t]{5}{*}{ Hydraulic Conductivity } & Sample A & .765 & .041 & .682 & .847 \\
\hline & Sample B & .968 & .041 & .885 & 1.050 \\
\hline & Sample C & 1.262 & .041 & 1.180 & 1.344 \\
\hline & Sample D & .974 & .041 & .892 & 1.057 \\
\hline & Sample E & 1.042 & .041 & .959 & 1.124 \\
\hline
\end{tabular}

Mean values of the different conductivities for the different sand samples used are shown in Table 2. It is seen that sample $\mathrm{E}$ has the highest thermal conductivity value (2.367), while sample $\mathrm{C}$ has the lowest thermal conductivity value (1.665).

Table 3. Mean values of the different conductivities properties for the different contaminants

3. Contaminant

\begin{tabular}{|ll|r|r|r|r|}
\hline & & & & \multicolumn{2}{|c|}{ 95\% Confidence Interval } \\
\cline { 5 - 6 } Dependent Variable & Contaminant & Mean & Std. Error & Lower Bound & \multicolumn{1}{c|}{ Upper Bound } \\
\hline Thermal Conductivity & Petrol & 1.674 & .042 & 1.591 & 1.758 \\
& Diesel & 2.297 & .042 & 2.213 & 2.381 \\
& Engine Oil & 1.458 & .042 & 1.375 & 1.542 \\
& H2SO4 & 2.868 & .042 & 2.784 & 2.952 \\
& Caustic Soda & 1.889 & .042 & 1.805 & 1.973 \\
\hline Electrical Conductivity & Petrol & 114.650 & .918 & 112.815 & 116.485 \\
& Diesel & 54.580 & .918 & 52.745 & 56.414 \\
& Engine Oil & 59.685 & .918 & 57.850 & 61.519 \\
& H2SO4 & 149.680 & .918 & 147.845 & 151.515 \\
& Caustic Soda & 158.242 & .918 & 156.408 & 160.077 \\
\hline Hydraulic Conductivity & Petrol & .708 & .041 & .626 & .790 \\
& Diesel & .420 & .041 & .338 & .503 \\
& Engine Oil & .446 & .041 & .363 & .528 \\
& H2SO4 & 1.230 & .041 & 1.148 & 1.312 \\
& Caustic Soda & 2.206 & .041 & 2.124 & 2.289 \\
\hline
\end{tabular}

Table 3 shows the mean values of the different conductivities for the different contaminants used. It is seen that $\mathrm{H} 2 \mathrm{SO} 4$ has the highest thermal conductivity value, (2.868) while Engine oil has the lowest thermal conductivity value (1.458). 
Table 4. Mean values of the different conductivities properties for the different concentration of contaminants

\section{Concentration of Contaminant}

\begin{tabular}{|ll|r|r|r|r|}
\hline & Concentration & & & \multicolumn{2}{|c|}{ 95\% Confidence Interval } \\
\cline { 5 - 6 } Dependent Variable & of Contaminant & Mean & Std. Error & Lower Bound & Upper Bound \\
\hline Thermal Conductivity & $5 \mathrm{ml}$ & 2.222 & .042 & 2.138 & 2.306 \\
& $10 \mathrm{ml}$ & 2.093 & .042 & 2.009 & 2.177 \\
& $15 \mathrm{ml}$ & 2.056 & .042 & 1.972 & 2.140 \\
& $20 \mathrm{ml}$ & 1.952 & .042 & 1.869 & 2.036 \\
& $25 \mathrm{ml}$ & 1.863 & .042 & 1.779 & 1.947 \\
\hline Electrical Conductivity & $5 \mathrm{ml}$ & 107.320 & .918 & 105.485 & 109.155 \\
& $10 \mathrm{ml}$ & 106.869 & .918 & 105.034 & 108.703 \\
& $15 \mathrm{ml}$ & 108.324 & .918 & 106.489 & 110.158 \\
& $20 \mathrm{ml}$ & 107.890 & .918 & 106.055 & 109.725 \\
& $25 \mathrm{ml}$ & 106.434 & .918 & 104.600 & 108.269 \\
\hline Hydraulic Conductivity & $5 \mathrm{ml}$ & 1.312 & .041 & 1.230 & 1.395 \\
& $10 \mathrm{ml}$ & 1.168 & .041 & 1.086 & 1.250 \\
& $15 \mathrm{ml}$ & .997 & .041 & .914 & 1.079 \\
& $20 \mathrm{ml}$ & .841 & .041 & .758 & .923 \\
& $25 \mathrm{ml}$ & .692 & .041 & .610 & .775 \\
\hline
\end{tabular}

It is observed from Table 4 that the thermal conductivity value is highest at $5 \mathrm{ml}$ concentration of the contaminants used while it is lowest at $25 \mathrm{ml}$ concentration of the contaminants used.

Table 5. Mean separation for thermal conductivity of different sand samples

\section{Thermal Conductivity}

Duncan a,b,c
\begin{tabular}{|l|r|r|r|r|r|}
\hline & & \multicolumn{5}{|c|}{ Subset } \\
\cline { 3 - 6 } Sample & $\mathrm{N}$ & 1 & 2 & 3 & 4 \\
\hline Sample C & 25 & 1.6652 & & & \\
Sample A & 25 & & 1.9228 & & \\
Sample B & 25 & & 2.0240 & & \\
Sample D & 25 & & & 2.2072 & \\
Sample E & 25 & & & & 2.3672 \\
Sig. & & 1.000 & .093 & 1.000 & 1.000 \\
\hline
\end{tabular}

Means for groups in homogeneous subsets are displayed.

Based on Type III Sum of Squares

The error term is Mean Square(Error) $=.044$.

a. Uses Harmonic Mean Sample Size $=25.000$.

b. The group sizes are unequal. The harmonic mean of the group sizes is used. Type I error levels are not guaranteed.

c. Alpha $=.05$.

From Table 5, mean separation for thermal conductivity of the different sand samples. It was observed from the table that thermal conductivity of sample A is not significantly different from that of sample B, while thermal conductivity of all other samples are significantly different at $5 \%(p<0.05)$ level. 
Table 6. Mean separation for hydraulic conductivity of different sand samples

Hydraulic Conductivity

\begin{tabular}{|c|c|c|c|c|}
\hline \multirow[b]{2}{*}{ Sample } & \multirow{2}{*}{$\mathrm{N}$} & \multicolumn{3}{|c|}{ Subset } \\
\hline & & 1 & 2 & 3 \\
\hline Sample A & 25 & .7648 & & \\
\hline Sample B & 25 & & .9676 & \\
\hline Sample D & 25 & & .9744 & \\
\hline Sample E & 25 & & 1.0416 & \\
\hline Sample C & 25 & & & 1.2620 \\
\hline Sig. & & 1.000 & .238 & 1.000 \\
\hline
\end{tabular}

Means for groups in homogeneous subsets are displayed.

Based on Type III Sum of Squares

The error term is Mean Square (Error) $=.043$.

a. Uses Harmonic Mean Sample Size $=25.000$.

b. The group sizes are unequal. The harmonic mean of the group sizes is used. Type I error levels are not guaranteed.

c. $\quad$ Alpha $=.05$.

Table 6 shows the mean separation for hydraulic conductivity of the different sand samples. It was observed from the table that hydraulic conductivity of sample B and D are not significantly different from that of sample E, while the hydraulic conductivity of sample A is significantly different from that of sample $\mathrm{C}$ at $5 \%$ level.

Table 7. Mean separation for electrical conductivity of different sand samples

\section{Electrical Conductivity}

Duncan a,b,c

\begin{tabular}{|l|r|r|r|r|}
\hline & \multirow{N}{*}{$\mathrm{N}$} & 1 & \multicolumn{3}{|c|}{ Subset } \\
\cline { 3 - 5 } Sample & 25 & 103.54 & & \multicolumn{1}{|c|}{3} \\
\hline Sample A & 25 & 104.13 & & \\
Sample C & 25 & & 107.55 & \\
Sample B & 25 & & 109.48 & \\
Sample D & 25 & & & 112.13 \\
Sample E & & .654 & .141 & 1.000 \\
Sig. & & & & \\
\hline
\end{tabular}

Means for groups in homogeneous subsets are displayed.

Based on Type III Sum of Squares

The error term is Mean Square(Error) $=21.085$.

a. Uses Harmonic Mean Sample Size $=25.000$.

b. The group sizes are unequal. The harmonic mean of the group sizes is used. Type I error levels are not guaranteed.

c. Alpha $=.05$.

Table 7 shows the mean separation for electrical conductivity of the different sand samples. It was observed from the table that electrical conductivity of sample $\mathrm{A}$ is not significantly different from that sample $\mathrm{C}$, while the electrical conductivity of sample B is not significantly different from that of sample $\mathrm{D}$, while electrical conductivity of sample $\mathrm{E}$ is significantly different from all other samples at $5 \%(\mathrm{p}<0.05)$ level. 
Table 8. Mean seperation for thermal conductivitiy of the sand samples for different contaminants used

\section{Thermal Conductivity}

Duncan ${ }^{\mathrm{a}, \mathrm{b}, \mathrm{c}}$
\begin{tabular}{|l|r|r|r|r|r|r|}
\hline \\
Contaminant & $\mathrm{N}$ & 1 & 2 & 3 & 4 & 5 \\
\hline Engine Oil & 25 & 1.4584 & & & & \\
Petrol & 25 & & 1.6744 & & & \\
Caustic Soda & 25 & & & 1.8888 & & \\
Diesel & 25 & & & & 2.2968 & \\
H2SO4 & 25 & & & & & 2.8680 \\
Sig. & & 1.000 & 1.000 & 1.000 & 1.000 & 1.000 \\
\hline
\end{tabular}

Means for groups in homogeneous subsets are displayed.

Based on Type III Sum of Squares

The error term is Mean Square(Error) $=.044$.

a. Uses Harmonic Mean Sample Size $=25.000$.

b. The group sizes are unequal. The harmonic mean of the group sizes is used. Type I error levels are not guaranteed.

c. Alpha $=.05$.

Mean separation for thermal conductivities of the sand samples for different contaminants used as shown in Table 8 . It is seen from the table that thermal conductivities of the sand samples differ significantly at $5 \%$ $(\mathrm{p}<0.05)$ level for the different contaminants used.

Table 9. Mean seperation for electrical conductivitiy of the sand samples for different contaminants used

Electrical Conductivity

Duncan ${ }^{\mathrm{a}, \mathrm{b}, \mathrm{c}}$
\begin{tabular}{|l|r|r|r|r|r|r|}
\hline \\
Contaminant & $\mathrm{N}$ & \multicolumn{5}{|c|}{ Subset } \\
\cline { 3 - 7 } & 25 & 54.58 & 2 & 3 & 4 & 5 \\
\hline Diesel & 25 & & 59.68 & & & \\
Engine Oil & 25 & & & 114.65 & & \\
Petrol & 25 & & & & 149.68 & \\
H2SO4 & 25 & & & & & 158.24 \\
Caustic Soda & & 1.000 & 1.000 & 1.000 & 1.000 & 1.000 \\
Sig. & & & & & \\
\hline
\end{tabular}

Means for groups in homogeneous subsets are displayed.

Based on Type III Sum of Squares

The error term is Mean Square(Error) $=21.085$.

a. Uses Harmonic Mean Sample Size $=25.000$.

b. The group sizes are unequal. The harmonic mean of the group sizes is used. Type I error levels are not guaranteed.

c. Alpha $=.05$.

Electrical conductivities of the sand samples differ significantly at $5 \%(\mathrm{p}<0.05)$ level for the different contaminants used as shown in Table 9. 
Table 10. Mean seperation for hydraulic conductivitiy of the sand samples for different contaminants used

\section{Hydraulic Conductivity}

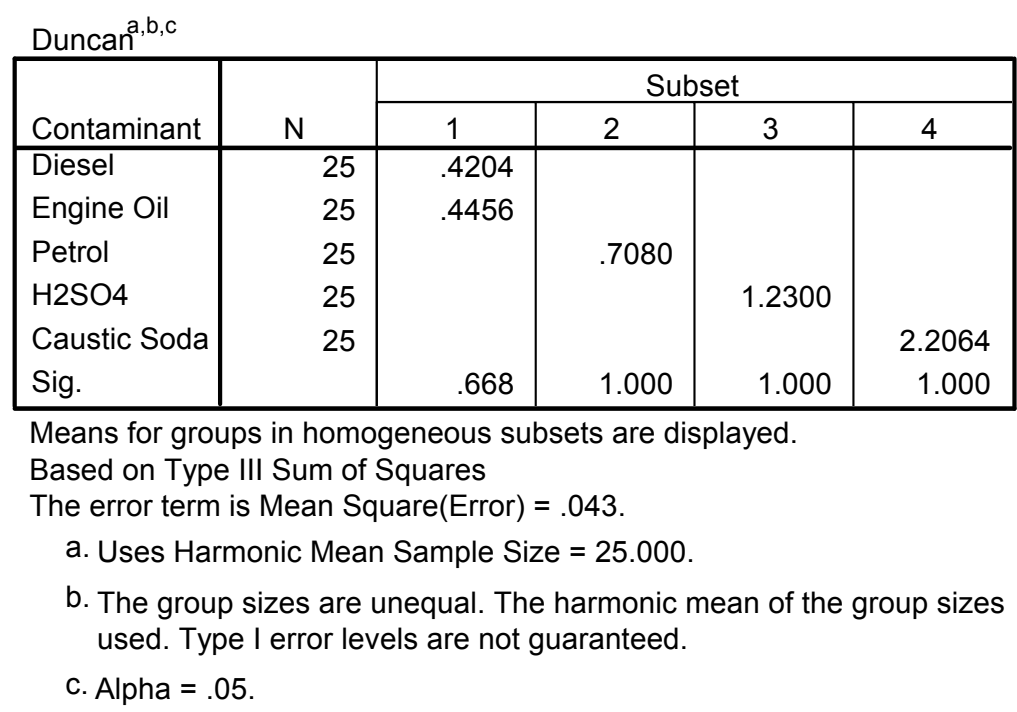

It is seen from the Table 10 that, hydraulic conductivity of diesel is not significantly different from that engine oil at $5 \%(\mathrm{p}<0.05)$ level for the different contaminants used. While hydraulic conductivities of other contaminants (petrol, $\mathrm{H} 2 \mathrm{SO} 4$ and caustic soda) are significantly different at $5 \%$ level.

Table 11. Mean seperation for thermal conductivitiy of the sand samples at different concentration of contaminants used

Thermal Conductivity

\begin{tabular}{|c|c|c|c|c|c|}
\hline \multirow{2}{*}{$\begin{array}{l}\text { Concentration } \\
\text { of Contaminant }\end{array}$} & \multirow[b]{2}{*}{$\mathrm{N}$} & \multicolumn{4}{|c|}{ Subset } \\
\hline & & 1 & 2 & 3 & 4 \\
\hline $25 \mathrm{ml}$ & 25 & 1.8628 & & & \\
\hline $20 \mathrm{ml}$ & 25 & 1.9524 & 1.9524 & & \\
\hline $15 \mathrm{ml}$ & 25 & & 2.0560 & 2.0560 & \\
\hline $10 \mathrm{ml}$ & 25 & & & 2.0932 & \\
\hline $5 \mathrm{ml}$ & 25 & & & & 2.2220 \\
\hline Sig. & & .136 & .085 & .533 & 1.000 \\
\hline
\end{tabular}

Means for groups in homogeneous subsets are displayed.

Based on Type III Sum of Squares

The error term is Mean Square (Error) $=.044$.

a. Uses Harmonic Mean Sample Size $=25.000$.

b. The group sizes are unequal. The harmonic mean of the group sizes is used. Type I error levels are not guaranteed.

c. Alpha $=.05$.

It was observed that thermal conductivity of the sand samples when $25 \mathrm{ml}$ concentration of the contaminants used is not significantly different at $5 \%$ level from when $20 \mathrm{ml}$ concentration of the contaminant is used as shown in Table 11 . Also the thermal conductivity does not differ at $5 \%$ level when $15 \mathrm{ml}$ concentration of the contaminant is used and when $20 \mathrm{ml}$ concentration of the contaminant is used, but that of $15 \mathrm{ml}$ differ significantly at $5 \%$ level from that of $25 \mathrm{ml}$. also thermal conductivity at $10 \mathrm{ml}$ concentration does not differ significantly at $5 \%(\mathrm{p}<0.05)$ level from that at $15 \mathrm{ml}$, but it differs significantly from those at other concentrations. Thermal conductivity at $5 \mathrm{ml}$ concentration is observed to be significantly different at $5 \%(\mathrm{p}<0.05)$ from those at other concentrations. 
Table 12. Mean seperation for electrical conductivitiy of the sand samples at different concentrations of contaminants used

\section{Electrical Conductivity}

\begin{tabular}{|l|r|r|} 
Duncan a,b,c & & \multicolumn{1}{|c|}{ Subset } \\
\cline { 3 - 3 } $\begin{array}{l}\text { Concentration } \\
\text { of Contaminant }\end{array}$ & $\mathrm{N}$ & \multicolumn{1}{|c|}{1} \\
\hline $25 \mathrm{ml}$ & 25 & 106.43 \\
$10 \mathrm{ml}$ & 25 & 106.87 \\
$5 \mathrm{ml}$ & 25 & 107.32 \\
$20 \mathrm{ml}$ & 25 & 107.89 \\
$15 \mathrm{ml}$ & 25 & 108.32 \\
Sig. & & .202 \\
\hline
\end{tabular}

Means for groups in homogeneous subsets are displayed.

Based on Type III Sum of Squares

The error term is Mean Square(Error) $=21.085$.

a. Uses Harmonic Mean Sample Size $=25.000$.

b. The group sizes are unequal. The harmonic mean of the group sizes is used. Type I error levels are not guaranteed.

c. Alpha $=.05$.

Table 12 shows the mean separation for the electrical conductivity of the sand samples at different concentrations of the contaminants used. It was observed that electrical conductivity of the sand samples are not significantly different at $5 \%(\mathrm{p}<0.05)$ level for the different concentration of contaminants used.

Table 13. Mean seperation for hydraulic conductivitiy of the sand samples at different concentration of contaminants used

\section{Hydraulic Conductivity}

\begin{tabular}{|c|c|c|c|c|c|c|}
\hline \multirow{2}{*}{$\begin{array}{l}\text { Concentratior } \\
\text { of Contamina }\end{array}$} & \multirow[b]{2}{*}{$\mathrm{N}$} & \multicolumn{5}{|c|}{ Subset } \\
\hline & & 1 & 2 & 3 & 4 & 5 \\
\hline \begin{tabular}{l|l}
$25 \mathrm{ml}$ &
\end{tabular} & 25 & .6924 & & & & \\
\hline $20 \mathrm{ml}$ & 25 & & .8408 & & & \\
\hline $15 \mathrm{ml}$ & 25 & & & .9968 & & \\
\hline $10 \mathrm{ml}$ & 25 & & & & 1.1680 & \\
\hline $5 \mathrm{ml}$ & 25 & & & & & 1.3124 \\
\hline Sig. & & 1.000 & 1.000 & 1.000 & 1.000 & 1.000 \\
\hline \multicolumn{7}{|c|}{$\begin{array}{l}\text { Means for groups in homogeneous subsets are displayed. } \\
\text { Based on Type III Sum of Squares } \\
\text { The error term is Mean Square(Error) }=.043 \text {. }\end{array}$} \\
\hline \multicolumn{7}{|c|}{ a. Uses Harmonic Mean Sample Size $=25.000$. } \\
\hline \multicolumn{7}{|c|}{$\begin{array}{l}\text { b. The group sizes are unequal. The harmonic mean of the group sizes } \\
\text { error levels are not guaranteed. }\end{array}$} \\
\hline C. Alpha $=.0$ & & & & & & \\
\hline
\end{tabular}

From Table 13, mean separation for the hydraulic conductivity of the sand samples at different concentrations of the contaminants used shown. It was seen from this table that the hydraulic conductivities of the sand samples differ significantly at $5 \%(p<0.05)$ level for the different concentration of contaminants used. 
Table 14. Regression analysis tables for thermal conductity of the sand sample

ANOVA

\begin{tabular}{|rl|r|r|r|r|r|}
\hline \multicolumn{1}{|l|}{} & \multicolumn{1}{|c|}{$\begin{array}{c}\text { Sum of } \\
\text { Model }\end{array}$} & Squares & df & Mean Square & F & Sig. \\
\hline 1 & Regression & 7.219 & 3 & 2.406 & 3.599 & $.016^{\mathrm{a}}$ \\
& Residual & 80.895 & 121 & .669 & & \\
& Total & 88.113 & 124 & & & \\
\hline
\end{tabular}

a. Predictors: (Constant), Concentration of Contaminant, Contaminant, Sample

b. Dependent Variable: Thermal Conductivity

Coefficients ${ }^{\mathrm{a}}$

\begin{tabular}{|c|c|c|c|c|c|c|}
\hline \multirow{2}{*}{\multicolumn{2}{|c|}{ Model }} & \multicolumn{2}{|c|}{$\begin{array}{c}\text { Unstandardized } \\
\text { Coefficients }\end{array}$} & \multirow{2}{*}{$\begin{array}{c}\text { Standardized } \\
\text { Coefficients }\end{array}$} & \multirow[b]{2}{*}{$t$} & \multirow[b]{2}{*}{ Sig. } \\
\hline & & $\mathrm{B}$ & Std. Error & & & \\
\hline & (Constant) & 1.673 & .278 & & 6.009 & .000 \\
\hline & Sample & .107 & .052 & .181 & 2.073 & .040 \\
\hline & Contaminant & .100 & .052 & .168 & 1.934 & .055 \\
\hline & $\begin{array}{l}\text { Concentration } \\
\text { of Contaminant }\end{array}$ & -.017 & .010 & -.145 & -1.661 & .099 \\
\hline
\end{tabular}

a. Dependent Variable: Thermal Conductivity

From the regression analysis results for thermal conductivity as shown in Table 14, it was observed that the thermal conductivity of the sand samples is significantly dependents at $5 \%$ level on the explanatory factors (concentration of contaminant, types of contaminant and sand sample) under consideration. These factors are responsible for $8.2 \%$ in the variation of the thermal conductivity of the sand sample. From the tables the regression equation as found to be $\mathrm{y}=0.107 \times 1+0.10 \times 2-0.017 \times 3+1.673$ as shown in Table 14

Where:

$\mathrm{y}=$ Sample Thermal conductivity, $\mathrm{x} 1=$ Sample density,

$\mathrm{x} 2=$ Contaminant thermal conductivity, $\mathrm{x} 3=$ Concentration of contaminant

Table 15. Regression analysis tables for electrical conductity of the sand sample

Coefficients $^{\mathrm{a}}$

\begin{tabular}{|c|c|c|c|c|c|c|}
\hline \multirow[b]{2}{*}{ Model } & & \multicolumn{2}{|c|}{$\begin{array}{c}\text { Unstandardized } \\
\text { Coefficients }\end{array}$} & \multirow{2}{*}{$\begin{array}{c}\begin{array}{c}\text { Standardized } \\
\text { Coefficients }\end{array} \\
\text { Beta }\end{array}$} & \multirow[b]{2}{*}{$\mathrm{t}$} & \multirow[b]{2}{*}{ Sig. } \\
\hline & & $B$ & Std. Error & & & \\
\hline & (Constant) & 47.173 & 14.153 & & 3.333 & .001 \\
\hline & Sample & 1.911 & 2.628 & .056 & .727 & .468 \\
\hline & Contaminant & 18.229 & 2.628 & .533 & 6.936 & .000 \\
\hline & $\begin{array}{l}\text { Concentration } \\
\text { of Contaminant }\end{array}$ & -.015 & .526 & -.002 & -.029 & .977 \\
\hline
\end{tabular}

a. Dependent Variable: Electrical Conductivity

ANOVA

\begin{tabular}{|ll|r|r|r|r|r|}
\hline \multicolumn{1}{|c|}{} & \multicolumn{1}{|c|}{ Sum of } & & & & \\
\hline 1 & & Squares & df & Mean Square & F & Sig. \\
\hline & Regression & 83984.351 & 3 & 27994.784 & 16.213 & $.000^{a}$ \\
& Residual & 208927.4 & 121 & 1726.673 & & \\
& Total & 292911.8 & 124 & & & \\
\hline
\end{tabular}

a. Predictors: (Constant), Concentration of Contaminant, Contaminant, Sample

b. Dependent Variable: Electrical Conductivity 
From the regression analysis results for electrical conductivity, it was observed that the electrical conductivity of the sand samples is significantly dependents at 5\% level on the explanatory factors (concentration of contaminant, types of contaminant and sand sample) under consideration. These factors are responsible for $28.7 \%$ in the variation of the electrical conductivity of the sand sample. From the tables the regression equation $\mathrm{y}=$ $1.911 \times 1+18.229 \times 2-0.015 \times 3+47.173$ as shown in Table 15

Where:

$\mathrm{y}=$ Sample Electrical conductivity, $\mathrm{x} 1=$ Sample density,

$\mathrm{x} 2=$ Contaminant electrical conductivity, $\mathrm{x} 3=$ Concentration of contaminant

Table 16. Regression analysis tables for hydraulic conductity of the sand sample

ANOVA $^{\text {b }}$

\begin{tabular}{|ll|r|r|r|r|r|}
\hline Model & & $\begin{array}{c}\text { Sum of } \\
\text { Squares }\end{array}$ & $\mathrm{df}$ & Mean Square & $\mathrm{F}$ & Sig. \\
\hline 1 & Regression & 43.147 & 3 & 14.382 & 51.496 & $.000^{\mathrm{a}}$ \\
& Residual & 33.794 & 121 & .279 & & \\
& Total & 76.941 & 124 & & & \\
\hline
\end{tabular}

a. Predictors: (Constant), Concentration of Contaminant, Contaminant, Sample

b. Dependent Variable: Hydraulic Conductivity

\section{Coefficients $^{\mathrm{a}}$}

\begin{tabular}{|c|c|c|c|c|c|c|}
\hline \multirow[b]{2}{*}{ Model } & & \multicolumn{2}{|c|}{$\begin{array}{c}\text { Unstandardized } \\
\text { Coefficients }\end{array}$} & \multirow{2}{*}{$\begin{array}{c}\text { Standardized } \\
\text { Coefficients } \\
\text { Beta }\end{array}$} & \multirow[b]{2}{*}{$t$} & \multirow[b]{2}{*}{ Sig. } \\
\hline & & $\mathrm{B}$ & Std. Error & & & \\
\hline & (Constant) & .162 & .180 & & .901 & .369 \\
\hline & Sample & .056 & .033 & .101 & 1.677 & .096 \\
\hline & Contaminant & .381 & .033 & .686 & 11.388 & .000 \\
\hline & $\begin{array}{l}\text { Concentration } \\
\text { of Contaminant }\end{array}$ & -.031 & .007 & -.282 & -4.689 & .000 \\
\hline
\end{tabular}

a. Dependent Variable: Hydraulic Conductivity

From the regression analysis results for hydraulic conductivity, it was observed that the hydraulic conductivity of the sand samples is significantly dependents at 5\% level on the explanatory factors (concentration of contaminant, types of contaminant and sand sample) under consideration. These factors are responsible for 56.1\% in the variation of the hydraulic conductivity of the sand sample. From the tables the regression equation $\mathrm{y}=$ $0.056 \times 1+0.381 \times 2-0.031 \times 3+0.162$ as shown in Table 16

Where:

$\mathrm{y}=$ Sample Hydraulic conductivity, $\mathrm{x} 1$ = Sample density,

$\mathrm{x} 2$ = Contaminant hydraulic conductivity, $\mathrm{x} 3=$ Concentration of contaminant

\section{Conclusion}

In this work, results of electrical conductivity, thermal conductivity and hydraulic conductivity have been modeled to determine effects of contaminants (petrol, diesel, engine oil, caustic soda and $\mathrm{H}_{2} \mathrm{SO}_{4}$ ) on conductive properties of riverbed sands. Duncan results showed that, thermal conductivity of sample A is not significantly different from that of sample B, while thermal conductivity of all other samples are significantly different at $5 \%$ $(\mathrm{p}<0.05)$ level. Electrical conductivity is not significantly different from that of sample $\mathrm{C}$ at $5 \%(\mathrm{p}<0.05)$ level, while hydraulic conductivity of samples B and D are not significantly different from that of sample E, but hydraulic conductivity of sample $\mathrm{A}$ is significantly different from that of sample $\mathrm{C}$ at $5 \%(\mathrm{p}<0.05)$ level.

Results from the coefficients of determination showed that concentration of contaminants, types of contaminants and sand samples are responsible for $8.2 \%$ in the variation of thermal conductivity, while these factors are also responsible for $28.7 \%$ and $56.1 \%$ in variation of electrical and hydraulic conductivities respectively. 


\section{References}

Amadi, A., Abbey, S. D., \& Nma, A. (1996). Chronic effects of oil spil on soil properties and microflora of rainforest ecosystem in Nigeria. Water Air Soil Pollut., 86, 1-11. http://dx.doi.org/10.1007/BF00279142

Chi Yuan Fan, \& Krishnamurthy, M. (1995). Enzymes for enhancing bioremediation of petroleum-contaminated soils: A brief review. Air Waste Manage. Assoc., 45, 453-460. http://dx.doi.org/10.1080/10473289.1995.10467375

Iwanow, W. N., Dylgierow, A. N., \& Stabnikowa, E. (1994). Aktivnost niekatorych ekołogo-troficzieskich grup mikroorganizmow pri zagraznienii cziernoziema obyknowiennowo ygliewodorami niefci. Mikrobiot. Zurn., 6, 59-63.

Jørgensen, K. S., Puustinen, J., \& Suortti, A. M. (2000). Bioremediation of petroleum hydrocarbon-contaminated soil by composting in biopiles. Environ. Pollut., 107, 245-254. http://dx.doi.org/10.1016/S0269-7491(99)00144-X

Joshua Paul Abrams. (2001). Mathematical modeling: Teaching the open ended application of mathematics

Leahy, J. G., \& Colwell, R. R. (1990). Microbial degradation of hydrocarbons in the environment. Microbiol. Rev. Sept., 54, 305-315.

Małachowska-Jutsz, A., Mrozowska, J., Kozielska, M., \& Miksch, K. (1997). Aktywność enzymatyczna w glebie skażonej związkami ropopochodnymi w procesie jej detoksykacji. Biotechnol., 36, 79-91.

Michalcewicz, W. (1995). Wpływ oleju napędowego do silników Diesla na liczebność bakterii, grzybów, promieniowców oraz biomasę mikroorganizmów glebowych. Rocz. PZH, 46, 91-97.

Neumaier, Amold. (2003). Mathematical modeling. Retrieved from http/www.mat.univie.ac.at/neum

Racine, Ch. H. (1993). Long-term recovery of vegetation on two experimental crude oil spills in interior Alaska black spruce taiga. Can. J. Bot., 72, 1171-1177. http://dx.doi.org/10.1139/b94-143

Song, H., \& Bartha, R. (1990). Effects of jet fuel spills on the microbial community of soil. Appl. Environ. Microb. Mar., 56, 646-651.

Sparrow, S. D., \& Sparrow, E. B. (1988). Microbial biomass and activity in a subartic soil ten years after crude oil spills. J. Environ. Qual., 17, 304-309. http://dx.doi.org/10.2134/jeq1988.00472425001700020024x

Sztompka, E. (1999). Biodegradation of engine oil in soil. Acta Microb. Pol., 489, 185-196.

Tyczkowski, A. (1993). Usuwanie zanieczyszczeń ropopochodnych z gleby i wód gruntowych metodami fizykochemicznymi i biotechnologicznymi. Ekol. Techn., 3, 10-13.

Wyszkowska, J., Kucharski, J., \& Wałdowska, E. (2002). The influence of diesel oil contamination on soil enzymes activity. Rostl. Výr., 48, 58-62.

Wyszkowska, J., Kucharski, J., Jastrzębska, E., \& Hłasko, A. (2001). The biological properties of the soil as influenced by chromium contamination. Polish J. Environ. Stud., 10, 37-42. 